\title{
Ortaokul öğrencilerinde Dijital Oyun Bağımlılığı ve Saldirganlik
}

\author{
DOI: 10.26466/opus.547092
}

*

\section{Burcu Güvendi* - Gönül Tekkurşun Demir** - Burçak Keskin***}

* Arş. Gör. Dr. İstanbul Üni.Cerrahpaşa, Spor Bilimleri Fak., Avcılar /İstanbul /Türkiye

E-Posta: burcu.guvendi@istanbul.edu.tr ORCID: 0000-0002-6170-9107

** Arş. Gör. Gazi Üniversitesi, Spor Bilimleri Fakültesi, Gazi / Ankara/ Türkiye

E-Posta: gonultekkursun@gazi.edu.tr ORCID: 0000-0002-2451-5194

*** Doç. Dr. İstanbul Üniversitesi Cerrahpaşa, Spor Bilimleri Fakültesi, Avcllar / İstanbul / Türkiye

E-Posta: burcakka@hotmail.com

ORCID: $\underline{0000-0003-4313-7720}$

\section{Öz}

Çalışmamızın amacı ortaokul öğrencilerinin dijital oyun bağımlılığının ve saldırganlık düzeylerinin bazı bağımsız değişkenlere göre incelenmesidir. Araştırmanın çalışma grubunu; İstanbul ilinin, Esenyurt ilçesine ait devlet okulunda okuyan yaş ort. 13.89.497 olan, $143 \mathrm{klz} 136$ erkek toplam 279 ortaokul öğrencisi oluşturmaktadır. Araştırmada veri toplama aracı olarak saldırganlı ölçeği ve çocuklarda dijital oyun bağımlılı̆̆ ölçeği kullanılmıştır. Araştırma bulgularında, öğrencilerin dijital oyun bağımlılığında riskli grupta yer aldıkları ve saldırgan davranışlar sergilemeye meyilli oldukları söylenebilir. Cinsiyete göre, ailenin dijital oyun oynama süresine sınır koyma durumlarına göre, ailenin fiziksel aktiviteye katılımı destekleme durumlarına göre, spor yapma durumlarına göre, dijital oyun oynama süresine ve dijital oyunu oynadı̆̆ 1 yere göre saldırganlık ölçeğinde ve dijital oyun bağımlılı̆̆ı ölçeğinde istatistiksel olarak anlaml farklılılar görülmüştür $(p<0.05)$. Korelasyon analizinde ise, saldırganlık ile dijital oyun bağımlılı̆̆ı ölçeği arasında pozitif yönde anlamlı düzeyde yüksek ilişki bulunmaktadır. Sonuç olarak, çocuklarının dijital oyun oynama süresine sınır koymayan ebeveynlerin çocuklarının, fiziksel aktiviteye katılmayan çocukların, düzenli spor yapmayan ve dijital oyun oynama süresi yüksek olan çocukların dijital oyun bağımlılı̆̆ı ile saldırganlık düzeylerinin yüksek olduğu sonucuna varılmıştır.

Anahtar Kelimeler: Saldırganlık, Dijital oyun, Öğrenci, Bă̆ımlılık 


\title{
Digital Game Addiction and Aggression in Secondary School Students
}

\begin{abstract}
The aim of our study is to investigate digital game addiction and aggression levels of secondary school students according to some independent variables. The study group of the research includes total 279

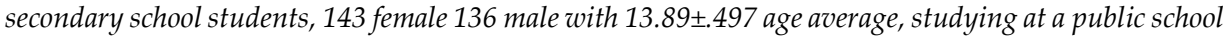
in Esenyurt, Istanbul. The scale of aggression developed by Gultekin (2008) and the scale of digital game addiction in children developed by Hazar and Hazar (2017) were used as data collection tools in the study. When the findings of the research are examined, it can be stated that students are in a risky group in digital game addiction and they tend to display aggressive behaviours. Statistically significant differences in aggression scale and digital game addiction scale $(p<0.05)$ were detected according to gender, cases of family's limiting the time of playing digital game, family's supporting to participate physical activity, doing sport, digital game playing time, and the place where digital game is played. In correlation analysis, there is a significant positive high correlation between aggression and digital gaming addiction scale. In conclusion, it has been concluded that digital game addiction and aggression levels of the children of parents, who do not limit the duration of their children's playing digital game, children not participating physical activity, not doing sport regularly, and playing digital game for a long time were found to be high.
\end{abstract}

Keywords: Aggression, Digital play, Student, Addiction 


\section{Giriş}

Saldırganlık, kimi zaman bireyi koruyucu bir kalkan gibi işlev görürken kimi zaman da hem birey hem de karşısındaki kişi ya da nesneler için olumsuz sonuçlar doğurabilmektedir. Özellikle birbirleriyle etkili bir iletişim kuramayan, birbirini anlayamayan bireylerin isteklerini yaptırabilmek ya da engellenme ile baş edebilmek için öfkelendiği ya da saldırgan davranışlara yöneldiği görülmektedir (Gültekin, 2008). Öfke, düşmanlık, rekabet, engellenme, korku gibi durumlardan kaynaklanan ve karşısındakine zarar vermeyi, onu durdurmay1, ona engel olmayı ya da kendini korumayı hedefleyen fiziksel, sözel veya sembolik her türlü davranıştır saldirganlık olarak ifade edilmektedir (Budak 2000).

Ergenlik, çocukluk ve erişkinlik arasında çeşitli fizyolojik, psikolojik ve sosyal değişikliklerin yaşandığı bir geçiş dönemi olması nedeniyle ergenin düşüncelerinde, duygularında ve davranışlarında dengesizliklere yol açan, fırtınalı ve stresli bir dönemdir. Dönemin zorluklarından biri de ergenlerin öfke denetimi, çatışma çözme, problem çözme ve iletişim gibi yaşam becerilerindeki yetersizliklerdir. Bu dönemde çeşitli sorunlarla karşılaşan ergen, gelişimsel zorluklar ve yaşam becerilerindeki yetersizlikler nedeniyle saldırgan davranışlara başvurabilir (Yavuzer, 2011). Ergenlik dönemi, karşılaşılan problemler ve geliştirilmesi gereken çözüm yolları bakımından zorlu yaşam dönemlerinden biridir (Kulaksızoğlu, 2002). Ortaokul öğrencileri de bulundukları yaş aralığı nedeniyle ergenlik dönemi içinde yer almaktadır (Törüner ve Büyükgönenç, 2012). Ergenlik dönemini yaşayan ortaokul öğrencileri bir taraftan kendini yetişkin sayarak tutum ve davranışını çevresindeki büyüklere göre ayarlarken diğer taraftan çocukluklarını yaşamaktadır (Öztürk, 2007). Çocukluk çağının vazgeçilmez en önemli parçası oyundur ve çocukların oyun tercihleri çocukların gelişimleri üzerinde önemli bir rol oynamaktadır. Çocukların oyun ve oyuncak türleri de değişen yaşama paralel olarak bu değişimden etkilenmektedir (Toran vd. 2016). Özellikle oyun oynama alanı ve oyun aracı olarak ortam sunan dijital dünya günümüzde çocuklar için oldukça popüler bir ortamdır (Bird ve Edwards, 2015). Ergenlerin oynadıları bilgisayar ve video gibi oyunlar bağımlılık yapabilmektedir. Ergen dijital oyun dediğimiz bu oyunları bir kez oynadıktan sonra sürekli oyun oynamak iste- 
mekte, kendisini uzak tutmak istese de bunu başaramamaktadır. Bu oyunlarla ergen, gerçek yaşamında yapamayacağı şeyleri başarmakta, başarı duygusunu yaşadıkçada daha çok zevk almaktadır. Oyunlarda gösterilen hırs gerçek hayatta olmamaktadır. Bu durum zaman zaman hayal perestliğe bile yol açmaktadır. Zihinsel gelişim üzerinde bazı oyunlar olumlu etki yaparken, bilgisayar oyunlarına bağımlılık çocukları ve ergenleri gerçeklikten ve gerçek yaşamdan uzaklaştırmaktadır (Pepe, 2011). Günümüzde bilişim teknolojilerinin gelişmesi dijital oyunların önemini arttırmıştır. Çocuklar bilgisayar başında zamanlarının çoğunu geçirmektedir. Bilgi teknolojilerindeki pazarın gelişmesi ve yaygınlaşması nedeniyle, teknolojiyi her an ve her yerden yakalayabildiklerinden dijital dünyadaki oyunlara rahatlıkla ulaşabilmektedirler. Çocuk dünyasını dijitalleştirerek yeniden inşa eden çok sayıdaki oyunlar, bir boş zaman değerlendirme aracı olarak, yorgunluk ve stres atmak için faydalı işlevleri yerine getirirken aynı zamanda içeriğinde şiddet öğeleri de barındırarak, şiddeti normal bir davranış haline getirebilmektedir. Çocuklar oynadıkları oyunlarda yer alan karakterlerle özdeşleşebilmekte ve mesajın içeriğindeki şiddet öğelerinden etkilendiğinin oyun içinde farkında değillerdir. Çocukların kısa ve uzun dönem bu oyunların tüketicisi olmaları, gündelik yaşamlarında şiddet ve şiddet olmayanın sınırları bulanıklaşabilmekte, gerektiğinde şiddeti bir sorun giderme biçimi olarak başvurulabilecek doğal bir eylem gibi algilayabilmektedirler (Karaaslan, 2015). Dijital oyunların ve kullanıcıların sayısında görülen artış dikkatleri oyunların etkileri üzerine çekmiştir. Dijital oyunların etkileri ile ilgili incelenen araştırmalar eğitici, öğretici ve geliştirici bilgisayar oyunlarının uygun zaman ölçüleri içinde ve kontrollü oynanmasının çocuk ve gencin gelişimine katkı sağladığını göstermiştir. Ancak dijital oyunların sahip olduğu bazı özellikler ve yaşattığı duygular oyuncuda bağımlılık gelişimini destekleyen unsurlar olarak ele alınmaktadır. Bu özellikler ve duygular oyuncuların dijital oyunlara uzun zaman harcamasına ve bağlanmasına yol açmaktadır (Irmak ve Erdoğan, 2015). Kars (2010) yaptığı çalışmasında bilgisayar oyunu oynama süresi arttıkça anti-sosyal saldırganlığın da arttığı sonucuna ulaşmıştır. Koçak ve Köse (2014) çalışmaların da bilgisayar oyunlarının, ergenlerin aile, okul ve arkadaşlık ilişkilerini, dolayısıyla da ergenin sosyalleşme sürecini olumsuz etkilediğini belirtmişlerdir. Torun ve ark. (2015)' 
na göre, oynanan oyunların türleri veya çocuğun oyunlara karşı bağımlılık düzeyleri, çocuğun kendine ve çevresine karşı olumsuz tavırlar sergilemesine neden olabilir (Torun, Akçay ve Çoklar, 2015). Saldırgan davranışların gelişmesinde bireysel, ailesel ve çevresel faktörlerin etkili olduğu bilinmektedir (Kaplan ve Aksel, 2013). Çocuklarda görülen saldırganlığa şiddet içerikli bilgisayar oyunlarının rekabet veya engellenme duyguları neden olabilir. özellikle kazanma/kaybetmeye dayalı şiddet içerikli oyunlarda çocuk çoğu zaman yenilir, yenildikçede daha fazla hırs yapar ve bu durum daha fazla öfkeye ve saldırganca davranışın görülmesine yol açabilir (Burak ve Ahmetoğlu, 2015).

Dijital ortamlarda kontrol edilemeyen çocukların izledikleri ya da oynadıkları oyunların çoğunda günümüzde giderek de artmakta olan ve çocukları etkisi altında bırakan çeşitli unsurlar yer almaktadır. Özelliklede silahla yaralama, öldürme oyunları, dövüş oyunları gibi sonunda kazanma kaybetmenin ve ödüllerin olduğu dijital oyunlar çocuğu gerçek hayatta da saldırganlığa itmektedir. Toksöz'e (1999) göre; şiddet içerikli bilgisayar oyunu kahramanın diğer karakterlerle sürekli kavga etmesini gerektirmektedir. Bu kavga oyundaki her hangi bir karakterin diğerini mağlup etmesi veya öldürmesi ile sonlanmaktadır. Gerçek yaşamda oyun bu kasıtla oynanmasa bile, yaşanan bu sürekli çatışma hali, oynayan kişinin saldırganlık düzeyinde artışa neden olabileceği düşünülmüştür (Toksöz, 1999). Bu bakımdan gelecek için sağlıklı bireyler yetiştirmenin, sokakta oyun oynayamayan ya da oynatılmayan, spor yapmayan ya da spora teşvik edilmeyen ve okul dışı boş vakitlerinde dijital oyun oynamak için sabırsızlıkla bekleyen çocukların çağı olan günümüz şartlarında oldukça zor olduğunu söyleyebiliriz.

Bu çalışma kültür farklılıklarının yoğun olarak gözlendiği, aile içi nüfusun fazla olduğu, aile eğitim seviyesi ve gelir durumu düşük olan, saldırganlık davranışları gösterme potansiyeli yüksek olarak kabul gören ve bu yüzden riskli bölge okulu adı altında geçen devlet okulunda gerçekleşmiştir. Bu bölgede yer alan okullarda dijital oyunun saldırganlık davranışları ile ilişkisinin araştırılmasının ve sonucunun ortaya konulmasının hem okul yönetimlerine hem milli eğitime hem de literatüre katkı sağlayacağı düşünülmektedir. Bu bağlamda çalışmamızın amacı ortaokul öğrencilerinin dijital oyun bağımlılığının ve saldırganlık düzeylerinin belirlenerek aralarındaki ilişkinin incelenmesidir. 


\section{Yöntem}

\section{Araştırma grubu}

Araştırmanın çalışma grubunu İstanbul ilinin Esenyurt ilçesine ait devlet

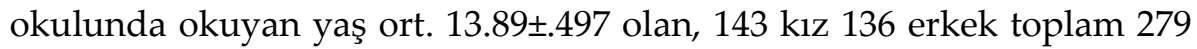

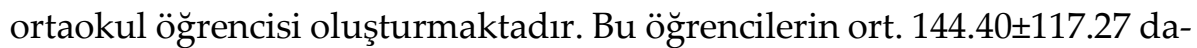
kika dijital oyun oynama süresi içinde yer aldıkları görülmüştür. Ayrıca çoğunluğunun annesi çalışmıyor ve interneti genellikle ya kendi telefonlarından ya da annelerinin telefonundan kullandıkları belirlenmiştir.

\section{Veri toplama araçları}

Araştırmada veri toplama aracı olarak saldırganlık ölçeği ve çocuklarda dijital oyun bağımlılığı ölçeği kullanılmıştır.

Saldırganlık Ölçeği: Ölçek, Gültekin (2008) tarafından geliştirilmiştir. Saldırganlık Ölçeği, ilköğretim ikinci kademe öğrencilerinin saldırganlık düzeylerini belirlemek amacıyla hazırlanmış 15 maddelik bir ölçektir. Likert tipi üçlü derecelendirmeyi içeren ölçekte öğrenciler her bir maddeyi "her zaman", "bazen", "hiçbir zaman" seçeneklerinden birini işaretleyerek cevaplandırmaktadırlar. Ölçek toplam puan veren bir ölçektir. Ölçekte "her zaman" seçeneğine 3, "bazen" seçeneğine 2, "hiçbir zaman" seçeneğine ise 1 puan verilmektedir. 15-45 arasında puan veren ölçekten alınan yüksek puan, saldırganlık düzeyinin yüksek olduğunu göstermektedir (Gültekin, 2008).

Çocuklarda Dijital Oyun Bağımlılı̆̆ı Ölçeği: Ölçek, Hazar ve Hazar (2017) tarafından geliştirilmiştir. 24 madde ve 4 alt boyuttan oluşmaktadır. Bu alt faktörler; "dijital oyun oynamaya yönelik aşırı odaklanma ve çatışma", "oyun süresinde tolerans gelişimi ve oyuna yüklenen değer", "bireysel ve sosyal görevlerin/ödevlerin ertelenmesi", "yoksunluğun psikolojik-fizyolojik yansıması ve oyuna dalma" olarak adlandırılmıştır. Ölçekteki ifadelerin değerlendirilmesinde 5 puanlı Likert tipi ölçekten yararlanılmıştır (1=Kesinlikle Katılmiyorum, 2=Katılmiyorum, 
3=Kararsızım, 4=Katılıyorum, 5=Tamamen Katılıyorum). Ölçekten alınabilecek en düşük puan "24" en yüksek puan "120" dir. Ölçek puanlamasının derecelendirmesinde ise; "1-24: Normal grup, 25-48: Az riskli grup, 49-72 Riskli grup, 73-96 Bağımlı grup, 97-120 Yüksek düzeyde bağımlı grup" olarak değerlendirilmektedir (Hazar ve Hazar, 2017).

\section{Verilerin Analizi}

Araştırmadan elde edilen verilerin analizinde SPSS 20 paket programı kullanılmıştır. Öncelikle verilerin normal dağılım gösterip göstermediğini belirlemek için Kolmogorov-Smirnov testi uygulanmış ve KolmogorovSmirnov testinden elde edilen $\mathrm{p}$ değerleri incelendiğinde elde edilen puanların dağılımının normal dağılıma uygun olduğu görülmüştür $(p>0,05)$. Verilerin değerlendirilmesinde istatistiki yöntem olarak; betimsel istatistikler (frekans, aritmetik ortalama, standart sapma); t testi, tek yönlü varyans analizi (ANOVA), Tukey çoklu karşılaştırma, Pearson korelasyon testleri kullanılmıştır.

\section{Bulgular}

Ortaokul öğrencilerinin dijital oyun bağımlılığının ve saldırganlık düzeylerinin belirlenerek aralarındaki ilişkinin incelenmesi amacıyla yapılan çalışmanın bulguları aşağıdaki gibidir;

Tablo 1. Ölçeklere Ait Ortalama Değerler

\begin{tabular}{lllll}
\hline Ölçekler & n & Min. & Max. & Ort. \pm Std. Sp. \\
\hline Saldırganlık & 279 & 15,00 & 41,00 & $20,61 \pm 5,62$ \\
\hline $\begin{array}{l}\text { Dijital Oyun } \\
\text { Bağımlılı̆̆ }\end{array}$ & 279 & 24,00 & 113,00 & $52,13 \pm 21,07$ \\
\hline
\end{tabular}

Tablo 1'de saldırganlık ölçeği ile çocuklar için dijital oyun bağımlılık ölçeğine ait ortalama değerler yer almaktadır. Buna göre öğrencilerin dijital oyun bağımlılığında riskli grupta yer aldıklar ve saldırgan davranışlar sergilemeye meyilli oldukları söylenebilir. 
Tablo 2. Ölçeklere Ait Korelasyon Analizi

\begin{tabular}{llc}
\hline Ölçekler & & Dijital Oyun Bağımlılığ \\
\hline \multirow{3}{*}{ Saldırganlık } & $\mathrm{r}$ &, $485^{* *}$ \\
& $\mathrm{p}$ &, 000 \\
& $\mathrm{n}$ & 279 \\
\hline
\end{tabular}

Tablo 2'de saldırganlık toplam puanı ile dijital oyun toplam puan ilişkinin tespit edilmesi için yapılan korelasyon testi yer almaktadır. Buna göre saldırganlık toplam boyutu ile dijital oyun bağımlılığı ölçeği toplam puanı arasında pozitif yönde anlamlı düzeyde yüksek ilişki bulunmaktadır $(\mathrm{r}=0,485, \mathrm{p}<0.05)$.

Tablo 3. Cinsiyete Göre Saldırganlık ve Dijital Oyun Bağımlılığı Ölçeğg $t$ Testi Sonuçları

\begin{tabular}{|c|c|c|c|c|c|}
\hline Ölçekler & Cinsiyet & $\mathbf{n}$ & Ort. \pm Std. Sp. & $t$ & $p$ \\
\hline \multirow{2}{*}{ Saldırganlık } & Kiz & 143 & $19,53 \pm 5,09$ & \multirow{2}{*}{$-3,342$} & \multirow[b]{2}{*}{,001 } \\
\hline & Erkek & 136 & $21,75 \pm 5,94$ & & \\
\hline \multirow{2}{*}{ Dijital Oyun Bağımlılığ1 } & $\mathrm{K}_{1 z}$ & 143 & $44,71 \pm 18,48$ & \multirow{2}{*}{$-6,436$} & \\
\hline & Erkek & 136 & $59,93 \pm 20,87$ & & ,000 \\
\hline
\end{tabular}

Tablo 3' de cinsiyete göre Saldırganlık toplam puanı $(\mathrm{t}(277)=-3,342, \mathrm{p}<0.05)$ ve dijital oyun bağımlılığı toplam puanında $(t(277)=-6,436, p<0.05)$ anlamlı farklılık tespit edilmiştir. Buna göre erkek (ort. $=21,75 \pm 5,94$ ) öğrencilerin kız (ort.=19,53 $\pm 5,09$ ) öğrencilere göre saldırganlık puanlarının yüksek olduğu görülmüştür. Bununla birlikte erkek (ort. $=59,93 \pm 20,87$ ) öğrencilerin kız (ort. $=44,71 \pm 18,48)$ öğrencilere göre dijital oyun bağımlılıkları daha yüksektir.

Tablo 4. Ailenin Dijital Oyun Oynamaya Sınır Koyma Durumuna Göre Saldırganlık ve Dijital Oyun Bă̆ımlılı̆̆ı Ölçeği t Testi Sonuçları

\begin{tabular}{|c|c|c|c|c|c|}
\hline Ölçekler & $\begin{array}{l}\text { Sinır } \\
\text { koyma }\end{array}$ & $\mathbf{n}$ & Ort. \pm Std. Sp. & $t$ & $p$ \\
\hline \multirow{2}{*}{ Saldırganlık } & Evet & 192 & $20,05 \pm 5,27$ & \multirow{2}{*}{$-2,370$} & \multirow{2}{*}{,019 } \\
\hline & Hayır & 87 & $21,86 \pm 6,17$ & & \\
\hline \multirow{2}{*}{ Dijital Oyun Bağımlılığ } & Evet & 192 & $50,29 \pm 20,68$ & \multirow{2}{*}{$-2,151$} & \multirow{2}{*}{,033 } \\
\hline & Hayır & 87 & $56,19 \pm 21,48$ & & \\
\hline
\end{tabular}


Tablo 4' de ailenin dijital oyun oynamaya sinır koyma durumuna göre Saldırganlık toplam puanı $(\mathrm{t}(277)=-2,370, \mathrm{p}<0.05)$ ve dijital oyun bağımlılığ 1 toplam puanında $(\mathrm{t}(277)=-2,151, \mathrm{p}<0.05)$ anlamlı farklılık tespit edilmiştir. Buna göre dijital oyun oynama süresine sınır koymayan ailelerin çocuklarının (ort. $=21,86 \pm 6,17$ ) saldırganlık puanlarınındijital oyun oynama süresine sınır koyan ailelerin çocuklarının (ort. $=20,05 \pm 5,27$ ) puanlarından anlamlı düzeyde yüksek olduğu görülmüştür. Ayrıca dijital oyun oynama süresine sınır koymayan ailelerin çocuklarının (ort. $=56,19 \pm 21,48$ ) dijital oyun bağımlılığ puanlarının, dijital oyun oynama süresine sınır koyan ailelerin çocuklarının(ort. $=50,29 \pm 20,68)$ puanlarından anlamlı düzeyde yüksek olduğu tespit edilmiştir.

Tablo 5. Ailenin Fiziksel Aktiviteye Katılımı Destekleme Durumuna Göre Saldırganlık ve Dijital Oyun Bă̆ımlılı̆̆ı Ölçeği t Testi Sonuçlan

\begin{tabular}{llllcc}
\hline \multirow{2}{*}{ Ölçekler } & $\begin{array}{l}\text { Fiziksel } \\
\text { aktiviteyi } \\
\text { destekleme }\end{array}$ & $\mathbf{n}$ & Ort. \pm Std. Sp. & $\boldsymbol{t}$ & $\boldsymbol{p}$ \\
\hline Saldırganlık & Evet & 233 & $20,01 \pm 5,10$ & $-4,151$ & $\mathbf{0 0 0}$ \\
\cline { 2 - 5 } Dijital Oyun Bağımlılı̆̆ & Hayır & 46 & $23,67 \pm 7,05$ & & \\
\cline { 2 - 5 } & Evet & 233 & $50,09 \pm 20,23$ & $-3,462$ &, $\mathbf{0 0 1}$ \\
\hline
\end{tabular}

Tablo $4^{\prime}$ de ailenin fiziksel aktiviteye katılımı destekleme durumlarına göre Saldırganlık toplam puanı $(\mathrm{t}(277)=-4,151, \mathrm{p}<0.05)$ ve dijital oyun bağımlılı̆̆ 1 toplam puanında $(\mathrm{t}(277)=-3,462, \mathrm{p}<0.05)$ anlamlı farklılık tespit edilmiştir $(\mathrm{p}<0.05)$. Buna göre fiziksel aktiviteye katılımı desteklemeyen ailelerin çocuklarının (ort. $=23,67 \pm 7,05$ ) saldırganlık puanlarının fiziksel aktiviteye katılımı destekleyen ailelerin çocuklarının (ort. $=20,01 \pm 5,10)$ puanlarından anlamlı düzeyde yüksek olduğu görülmüştür. Ayrıca fiziksel aktiviteye katılımı desteklemeyen ailelerin çocuklarının (ort.=62,43 $\pm 22,43$ ) dijital oyun bağımlılı̆̆ı puanlarının fiziksel aktiviteye katılımı destekleyen ailelerin çocuklarının (ort.=50,09 $\pm 20,23$ ) puanlarından anlamlı düzeyde yüksek olduğu tespit edilmiştir. 
Tablo 6. Dijital Oyun Oynama Süresi Göre Saldırganlık ve Dijital Oyun Bă̆ımlılı̆̆ Ölçeği Anavo Analiz Sonuçlarn

\begin{tabular}{|c|c|c|c|c|c|c|}
\hline Ölçekler & Oyun Süresi & $\mathbf{n}$ & Ort. \pm Std. Sp. & $\mathbf{F}$ & $\mathrm{p}$ & Tukey \\
\hline \multirow{3}{*}{ Saldırganlık } & $0-60 \mathrm{dk}$ & 103 & $19,26 \pm 4,80$ & \multirow{3}{*}{7,175} & \multirow{3}{*}{,001 } & \multirow{3}{*}{$1-3$} \\
\hline & $61-120 \mathrm{dk}$ & 77 & $20,41 \pm 5,81$ & & & \\
\hline & 121ve üzeri & 99 & $22,18 \pm 5,92$ & & & \\
\hline \multirow{3}{*}{$\begin{array}{l}\text { Dijital Oyun } \\
\text { Bağımlılığı }\end{array}$} & $0-60$ & 103 & $44,91 \pm 18,39$ & \multirow{3}{*}{11,759} & \multirow{3}{*}{,000 } & \multirow{3}{*}{$\begin{array}{l}1-2 \\
1-3\end{array}$} \\
\hline & $61-120$ & 77 & $53,41 \pm 21,61$ & & & \\
\hline & 121ve üzeri & 99 & $58,64 \pm 21,13$ & & & \\
\hline
\end{tabular}

Tablo 6' da dijital oyun oynama süresine göre saldırganlık toplam puanı $(\mathrm{F}(2,276)=7,175, \mathrm{p}<0.05)$ ve dijital oyun bağımlılığ $(\mathrm{F}(2,276)=11,759, \mathrm{p}<0.05)$ anlamlı farklılık tespit edilmiştir. Buna göre dijital oyunu $121 \mathrm{dk}$ ve üzerinde oynayan öğrencilerin (ort.=22,18 $\pm 5,92$ ) saldırganlık puanlarının 0-60dk arasında oynayan öğrencilerin (ort.=19,26 $\pm 4,80$ ) puanlarından anlamlı düzeyde yüksek olduğu görülmüştür. Ayrıca dijital oyunu 0-60dk arasında oynayan öğrencilerin puan ortalamalarinın (ort. $=44,91 \pm 18,39) \quad 61-120 \quad \mathrm{dk}$ oynayanlardan (ort. $=53,41 \pm 21,61$ ) ve 121 ve üzeri $\mathrm{dk}$ arasında oynayan öğrencilerin puanlarından (ort. $=58,64 \pm 21,13$ ) anlamlı düzeyde düşük olduğu görülmüştür.

Tablo 7. Dijital Oyunu Nerede Oynadı̆̆ına Göre Saldrrganlık ve Dijital Oyun Bağımlılı̆̆ Ölçeği Anavo Analiz Sonuçları

\begin{tabular}{|c|c|c|c|c|c|c|}
\hline Ölçekler & $\begin{array}{l}\text { Nerede } \\
\text { oynuyorsun? }\end{array}$ & $\mathbf{n}$ & Ort. \pm Std. Sp. & $\mathbf{F}$ & $\mathbf{p}$ & Tukey \\
\hline \multirow{4}{*}{ Saldırganlık } & Anne Telefon & 84 & $20,26 \pm 5,12$ & \multirow{4}{*}{$-6,801$} & \multirow{4}{*}{,000 } & $3-1$ \\
\hline & Baba Telefon & 51 & $18,41 \pm 4,38$ & & & $3-2$ \\
\hline & İnternet kafe & 20 & $24,60 \pm 7,36$ & & & $3-4$ \\
\hline & KendisineAit & 124 & $21,12 \pm 5,71$ & & & $4-2$ \\
\hline \multirow{4}{*}{$\begin{array}{l}\text { Dijital } \\
\text { Oyun Bağımlılığı }\end{array}$} & Anne Telefon & 84 & $49,22 \pm 19,23$ & \multirow{4}{*}{$-6,034$} & \multirow{4}{*}{,001 } & \\
\hline & Baba Telefon & 51 & $46,31 \pm 20,15$ & & & $\begin{array}{ll}3-1 \\
3-2\end{array}$ \\
\hline & İnternet kafe & 20 & $67,55 \pm 20,13$ & & & $\begin{array}{l}3-2 \\
3-4\end{array}$ \\
\hline & KendisineAit & 124 & $54,00 \pm 21,55$ & & & \\
\hline
\end{tabular}

Tablo 7' de dijital oyunu oynama yerinegöre yapılant testi analiz sonuçları yer almaktadır. Saldırganlık toplam puanı $(\mathrm{F}(3,275)=6,801, \mathrm{p}<0.05)$ ve dijital oyun bağımlılığ1 toplam puanında $(\mathrm{F}(3,275)=6,034, \mathrm{p}<0.05)$ anlamlı 
farklılık tespit edilmiştir. Buna göre dijital oyun oynamak için internet kafeye giden öğrencilerin( ort. $=24,60 \pm 7,36$ ) saldırganlık puanlarının annesinin telefonunu kullanan (ort. $=20,26 \pm 5,12$ ), babasinin telefonu kullanan (ort. $=18,41 \pm 4,38$ ) ve kendisine ait telefonu kullanan (ort.=21,12 $\pm 5,71$ ) öğrencilerin puanlarından anlamlı düzeyde yüksek olduğu görülmüştür. Ayrıca dijital oyun oynamak için internet kafeye giden öğrencilerin(ort. $=67,55 \pm 20,13$ ) dijital oyun bağımlılı̆̆ 1 puanlarının annesinin telefonunu kullanan (ort. $=49,22 \pm 19,23$ ), babasının telefonu kullanan (ort. $=46,31 \pm 20,15)$ ve kendisine ait telefonu kullanan (ort. $=54,00 \pm 21,55)$ öğrencilerin puanlarından anlamlı düzeyde yüksek olduğu görülmüştür.

\section{Tartışma ve sonuç}

Ortaokul öğrencilerinin saldırganlık ve dijital oyun bağımlılığı düzeyi arasındaki ilişkinin çeşitli demografik bilgiler açısından incelenmesinin amaçlandığı bu araştırmaya 143 kız 136 erkek toplam 279 ortaokul öğrencisi katılmıştır.

Araştırmanın ilk bulgusunda yer alan çocuklar için dijital oyun bağımlılık ölçeğine ait ortalama değerlerine göre katılımcıların riskli grupta yer aldıkları tespit edilmiştir. Bu bağlamda riskli grupta yer alan katılımcıların ortalama puanlara bakıldığında saldırgan davranışlar sergilemeye meyilli oldukları söylenebilir.

Araştırmanın diğer bulgusunda katılımcıların cinsiyetlerine göre bakıldığında erkek öğrencilerin kız öğrencilere göre saldırganlık ve dijital oyun bağımlılı̆̆ toplam puanında anlamlı farklılık tespit edilmiştir. Buna göre erkek öğrencilerin kız öğrencilere göre saldırganlık ve dijital oyun bağımlılık düzeylerinin daha yüksek olduğu saptanmıştır. Bu bağlamda erkek katılımcıların kadınlara göre dijital oyunlara daha düşkün olduğu, bu oyunlara daha fazla zaman ayırdığ empati duygusundan uzaklaştırarak saldırganlık duygusunu yükselttiği söylenebilir. Bunun nedeni olarak Türk kültür yapısında kız çocuklarının daha fazla ev ortamında sorumluluklarının olmasından dolayı dijital oyuna zaman ayıramaması ve internet kafeye daha çok erkeklerin gitmesinden kaynaklandığı düşünülebilir. Hazar vd. (2017)'nin araştırmasında da araştırma sonucuna paralel olarak erkeklerin dijital oyun bağımlılığı 
düzeyleri kadınlara kıyasla anlamlı düzeyde yüksek bulunmuştur. Horzum (2011) da ilköğretime devam eden erkek öğrencilerinin bağımlılık düzeylerinin kız öğrencilere göre anlamlı düzeyde yüksek olduğu sonucuna ulaşmıştır. Benzer şekilde Gökçearslan ve Seferoğlu (2016) erkeklerin riskli İnternet davranış düzeylerinin kızlarınkinden daha yüksek olduğunu belirtmiştir. Kars (2010) çalışmasında erkeklerin kızlardan daha fazla bilgisayar oyunu oynadıkları ve erkeklerin kızlardan daha fazla şiddet içerikli bilgisayar oyunu oynadıkları belirtmiştir. Gönültaş ve Atıcı (2014)'nın çalışmasında erkek öğrencilerin öfke ve saldırganlık puanları kız öğrencilerin öfke ve saldırganlık puanlarına göre yüksek çıkmıştır. Kaplan ve Aksel (2013) tarafından ergenler üzerinde yapılan çalışmada erkeklerin kızlara göre daha yüksek saldırganlık puanına sahip oldukları sonucuna ulaşmışlardır. Yılmaz (2013)'ın çalışmasında kız öğrencilerin erkek öğrencilere göre saldırganlık düzeylerinin daha düşük olduğu bulunmuştur. Karaaslan (2015)' da araştırmasında erkeklerin daha fazla teknolojiye yakın olduğundan dijital oyunlara eğilimlerinin kızlara göre daha yüksek olduğunu belirtmiştir. Ayrıca Karaaslan (2015)'nın çalışmasında, şiddet oyunlarını erkeklerin kızlara göre daha fazla oynadığı, cinsiyete göre çocukların şiddet içeren oyunlardan etkilenmeleri arasında da $\% 5$ anlamlılık düzeyinde bir ilişkinin olduğunu ve erkeklerin oyunlardaki şiddeti kızlara göre daha çok taklit ettikleri ve cinsiyete göre çocukların dijital oyunlardaki şiddeti taklit etmeleri arasında anlamlı bir ilişki olduğu sonucuna ulaşmış ve buna bağlı olarak erkeklerin şiddeti taklit ettiklerinden saldırganlık davranışlarının da paralel olarak kızlara göre daha fazla olduğunu belirtmiştir. Benzer araştırma sonuçlarının alan yazında oldukça sık yer aldığ 1 görülmektedir ve bu farkın temel nedeni olarak da benzer ifadeler kullanılmaktadır (Erboy, 2010; Akçay ve Özcebe, 2012; Keneer vd., 2014; Irles ve Gornis, 2015).Demir ve Cicioğlu (2019)'nun araştırmasında araştırma bulgularından farklı olarak dijital oyun oynama motivasyonu ile fiziksel aktiviteye katılım motivasyonunun cinsiyete göre farkl1lık göstermediği saptanmıştır.

Araştırmada katılımcıların saldırganlık ve çocuklar için dijital oyun bağımlılığı ölçeğinden aldıkları puanların ailenin dijital oyun oynamaya s1nır koyma durumlarına göre farklılaştı̆̆ saptanmıştır. Buna göre dijital oyun oynama süresine sınır koymayan ailelerin çocuklarının saldırganlık ve dijital oyun bağımlılığı düzeylerinin, dijital oyun oynama süresine sınır 
koyan ailelerin çocuklarından anlamlı düzeyde yüksek olduğu tespit edilmiştir. Buna neden olarak çocuklarının dijital oyun oynama süresine sınır koymayan ebeveynlerin çocuklarının iletişim bozukluğu ve gerçek yaşama ayak uyduramama gibi sorunlar yaşayarak saldırganlık duygularının dijital oyun oynama süresine sınır koyan ebeveynlerin çocuklarından yüksek olmasına zemin hazırladığı söylenebilir. Nitekim Kaya'ya göre (2013) yaşamın pek çok alanı gerçek yaşamdan farklı olarak sanallaşmıştır ve bu sanallıklardan birisi de dijital oyunlardır. Ayrıca dijital oyun oynama süresi kısıtlanmadığında Demir ve Hazar (2018)'a göre geçlerin fiziksel aktiviteye katılım, hareket etmekten uzaklaşma, görev ve ihtiyaçlarını aksatma gibi pek çok hayati öneme sahip olan durumları göz ardı etmelerine neden olmaktadır. Buna ek olarak Çakır (2013) araştırmasında dijital oyunlara ayrılan zamandan dolayı bireylerin diğer aktivitelerden yoksun kaldığını belirtmiş̧tir. Pepe (2011) ise ailelerin bilgisayar oyunlarına yönelik tutumları; \%52.8'i ilgisiz, \%36.1'i karşı ve \%11,12'inin de bilgisayar oyunu oynamalarını desteklediği saptamıştır. Koçak ve Köse (2014) tarafından ergenlerin bilgisayar kullanımları ile ilgili yapılan çalışmada katılımcıların neredeyse yarsısının bilgisayarda oyun oynama sürelerini kendilerinin belirlediklerin, diğer yarısının da (yaklaşık olarak) bilgisayarda oyun oynama sürelerini anne babalarının belirlediklerini ifade etmişlerdir. Bu durum iki açıdan değerlendirilmelidir. Koçak ve Köse (2014)' e göre ergenin oyun süresini kendisinin belirlemesi bir yönüyle görev ve sorumluluk gelişimi açısından olumlu bir kazanım gibi görülebileceği gibi, ergenin bilgisayarda oyun oynama süresine kimsenin karışmaması açısından değerlendirildiğinde ise ailede önemli bir sorun olarak görülebilir.

Araştırmada katılımcıların saldırganlık ve çocuklar için dijital oyun bağımlılığı ölçeğinden aldıkları puanların ailenin fiziksel aktiviteye katılımı destekleme durumlarına göre farklılaştığı saptanmıştır. Buna göre fiziksel aktiviteye katılımı desteklemeyen ailelerin çocuklarının saldırganlık ve dijital oyun bağımlılığı düzeyinin fiziksel aktiviteye katılımı destekleyen ailelerin çocuklarınınkinden anlamlı düzeyde yüksek olduğu tespit edilmiştir. Buna neden olarak fiziksel aktiviteye katılan çocukların günlük stres, kaygı ve problemlerini fiziksel aktiviteye katılarak unutmalarından, deşarj olmalarından dolayı saldırganlık düzeylerinin düştüğü söylenebilir. Ayrıca fiziksel aktiviteye katılan çocukların dijital oyunlara daha az 
zaman ayırması bekleneceği için dijital oyun bağımlısı olmaması beklenir. Hazar vd. (2017)'nin araştırmasında araştırma sonucuna paralel olarak fiziksel aktiviteye katılım arttıkça bağımlılığın düştüğü saptanmıştır. Demir ve Cicioğlu (2019)'nun araştırmasında da dijital oyun oynama motivasyonu arttıkça fiziksel aktiviteye katılım motivasyonunun azaldığı saptamıştır. Buna göre spor yapan çocukların saldırganlık ve dijital oyun bağımlılığı puanlarının spor yapmayan çocukların puanlarından anlamlı düzeyde yüksek olduğu saptanmıştır. Buna neden olarak düzenli spor yapmanın bireyleri daha aktif ve hareketli yaşama alıştırmasından dolayı genellikle yerinde hareketsiz oynanan dijital oyunlardan uzaklaştırdığ 1 düşünülebilir. Spor yapan katılımcıların bilişsel, sosyal, duyuşsal ve fiziksel açıdan iyi oluş düzeyine ulaştıkları için saldırganlık düzeyinin düştüğü düşünülebilir. Çalışmamızdan farklı olarak, Hazar vd. (2017)'nin araştırmasında araştırma sonucuna paralel olarak düzenli spor yapan katılımcların dijital oyun bağımlılıklarının düzenli spor yapmayanlara göre anlamlı düzeyde düşük olduğunu tespit etmiştir. Yılmaz (2013) spor yapan öğrencilerin saldırgan davranışlarının spor yapmayanlara göre daha düşük seviyede olduğu sonucuna ulaşmıştır. Alp, Eraslan, Atay ve Özmutlu (2014) tarafından yapılan çalışmada cinsiyete göre saldırganlık düzeyinde spor yapan ve yapmayan öğrenciler arasında anlamlı farklılık olmadığını saptamıştır. Başka bir ifade ile düzenli spor aktivitelerine katılımın saldırganlık düzeyi üzerine etkisinin olmadığı bulunmuştur. Çebi, Yamak ve Öztürk (2016) ise düzenli olarak spor yapan ve yapmayan 1114 yaş arası ortaokul öğrencilerinin duygu kontrol düzeyleri spor yapanlar lehine anlamlı bir farklılık gösterdiğ ini belirtmiştir.

Araştırmada katılımcıların saldırganlık ve çocuklar için dijital oyun bağımlılı̆̆ 1 ölçeğinden aldıkları puanların dijital oyun oynama süresine göre farklılık gösterdiği saptanmıştır. Buna göre dijital oyunu $121 \mathrm{dk}$ ve üzerinde oynayan öğrencilerin saldırganlık puanlarının0-60dk arasında oynayan öğrencilerin puanlarından anlamlı düzeyde yüksek olduğu tespit edilmiştir. Buna neden olarak uzun süre dijital oyun oynayan çocukların çevre ile iletişimin azalmasına ve karşısındakinin yerine kendini koyma becerisinin azalmasına neden olarak saldırgan, sabırsız davranışlar sergilemesine sebep olabilir. Ayrıca dijital oyunu 0-60dk arasında oynayan öğrencilerin puan ortalamalarının61-120 dk oynayanlardan ve 121 ve üzeri $\mathrm{dk}$ arasında oynayan öğrencilerin puanlarından anlamlı düzeyde düşük 
olduğu görülmüştür. Buna neden olarak dijital oyun süresi arttıkça kişinin bu oyunlara olan ilgi ve alakasının artması ile dijital oyuna ayrılan zaman gün geçtikçe artabilir bu da bağımlılık olgusunu yanında getirebilir. Hazar vd. (2017)'nin araştırmasında da araştırma bulgularına paralel olarak dijital oyun oynama süresi arttıkça dijital oyun bağımlılığının arttığ1 saptanmıştır. Gökçearslan ve Durakoğlu (2014), ile Festl, Scharkow ve Quandt (2016)'un ergenlerle yaptığı araştırmasında dijital bağımlılığın oynama süresi ile pozitif yönde ilişkili olduğu saptanmıştır. Demir ve Cicioğlu (2019)'un araştırmasında araştırma bulgularından farklı olarak, dijital oyun oynama süresine göre dijital oyun oynama motivasyonun, günlük 0-60 dakika dijital oyun oynayan öğrencilerin puan ortalamalarının, 61-120 dakika, 121 ve üstünde dijital oyun oynayanların puan ortalamasından anlamlı düzeyde yüksek olduğu saptanmıştır. Koçak ve Köse (2014) tarafından yapılan çalışmada katılımcılardan her gün bilgisayar oyunu oynayanların ve haftada 3-4 gün oynadığını belirtenlerin, bilgisayar oyunu bağımlısı ya da bağımlılık yolunda olduklarını belirlenmiştir. Karaaslan (2015) göre, ortaöğretimdeki çocuklar yaşları gereği aile kontrolünü kabul etmemekte, kendi öz benlik bilinçleri yoluyla sorunun çözümünün daha uygun olacağını varsaymaktadırlar . Ebeveynler dıştan gelen kontrol etkisinin bu soruna çözüm olamayacağını düşünmektedirler. Bu yönüyle yapılan çalışma, okul ve aile tarafından, şiddet içerikli oyunları çocukların oynamaması, onların bilinçlendirilmesi yönünde yapılacak seminer ve konferansların alana önemli katkılar sağlayacağını göstermektedir. Aileler bilişim çağının gerekleri içinde dijital oyunların ortaya çıkardığı bağımlılıkların farkındadırlar. Genel olarak, farkındalıklarının gerektirdiği müdahaleleri aileler yerine getiremediği bu nedenlede ailelerin, toplumda sosyal projeler aracılığı ile bilinçlendirilmeleri gerektiği söylenebilir.

Araştırmada katılımcıların dijital oyunu oynadıkları yere göre saldırganlık ve çocuklar için dijital oyun bağımlılığı ölçeğinden aldıkları puanlarında farklılaşma tespit edilmiştir. Buna göre dijital oyun oynamak için internet kafeye giden öğrencilerin saldırganlık puanlarının annesinin, babasının ve kendi telefonunu kullanan öğrencilerin puanlarından anlamlı düzeyde yüksek olduğu görülmüştür. Ayrıca dijital oyun oynamak için internet kafeye giden ögrencilerin dijital oyun bağımlılığı puanlarının an- 
nesinin, babasının ve kendi telefonunu telefonu kullanan öğrencilerin puanlarından anlamlı düzeyde yüksek olduğu görülmüştür. Buna neden olarak dijital oyunları ebeveyn telefonundan ya da kendi telefonundan oynayan çocukların genellikle ebeveyn gözetiminde, ev ortamında olmalarından dolayı az da olsa aile içinde iletişimde olmalarını doğurabilir. Fakat internet kafede dijital oyun oynayan çocukların farkında olmadan uzun süre harcamalarına, ayrıca daha çok kendi içine kapanarak, sosyalleşmek ve empati duygularından uzaklaşmaları söz konusu olabilir. Bu durum da dijital bağımlılığının ortaya çıkmasının yanı sıra saldırganlık duygusunun da artmasını tetikleyebilir. Günümüz gençlerinin teknoloji ile iç içe olması, teknolojiyi kullanarak büyümesi, onların geleneksel oyun yerine teknolojik aletler ile ilgilenmelerine neden olmaktadır (Demir ve Bozkurt, 2019). Bu durum dijital bağımlılığına neden olmaktadır. Dijital oyuna bireyleri iten nedenlerden biri de Kaya (2013) ile Horzum, Ayaş ve Çakır-Balta (2008)'ya göre oyun parklarının kullanımının azalması, bu nedenle de çocukların sanal ortamlara yönelmesidir. 9-16 yaş grubunda yer alan 25 bin öğrenciye ulaşılan Avrupa Çevrimiçi Çocuklar (EU Kids Online) projesinin raporuna göre; Türkiye "düşük düzey İnternet kullanımı" ve "biraz riskli" grupta yer almaktadır. Türkiye'de çocukların \% 36's1 günde 1 saatten fazla İnternet kullanmakta, \% 52'si İnternet'e evden bağlanırken, buna yakın bir oranda kullanıcı da İnternet kafelerden İnternet'e erişim sağlamaktadır (Gökçearslan ve Seferoğlu, 2016).

Araştırmanın son bulgusunda saldırganlık toplam boyutu ile dijital oyun bağımlılığı ölçeği toplam puanı arasında pozitif yönde anlamlı düzeyde yüksek ilişki bulunmaktadır. Buna göre ortaokul öğrencilerinin dijital oyun bağımlılığı arttıkça saldırganlık düzeylerinin arttığı söylenebilir. Buna neden olarak dijital oyunlara bağımlı olan bireylerin saldırganlaşma gibi istenmeyen olumsuz duygular geliştirmesine neden olduğu söylenebilir.

Sonuç olarak ortaokul öğrencilerinin saldırganlık ve dijital oyun bağımlılık düzeyleri arasında yüksek düzeyde ilişki saptanmıştır. Buna göre dijital oyun bağımlılığı arttıkça öğrencilerin saldırganlık davranışlarının da arttığı söylenebilir. Koçak ve Köse (2014) yaptıkları çalışmada bilgisayar oyunlarının, ergenlerin aile, okul ve arkadaşlık ilişkilerini, dolayısıyla da ergenin sosyalleşme sürecini olumsuz etkilediğini ayrıca bazı ergenlerin, daha çok yüz yüze iletişimden uzaklaştıkları ve bireysel bir yaşamı tercih 
ettiklerini ve bilgisayarda savaş oyunu oynayan ergenlerin şiddete meyilli oldukları sonuna ulaşmıştır. Katılımcların Hazar ve Hazar (2017)'ın belirttiği dijital oyun bağımlılığı skalasında riskli grupta yer aldığı, erkeklerin kadınlardan yüksek saldırganlık ve dijital oyun bağımlılığı düzeyine sahip olduğu sonucuna varılmıştır. Çocuklarının dijital oyun oynama süresine sınır koymayan ebeveynlerin çocuklarının, fiziksel aktiviteye katılmayan çocukların, düzenli spor yapmayan ve dijital oyun oynama süresi yüksek olan çocukların dijital oyun bağımlılığı ile saldırganlık düzeylerinin yüksek olduğu sonucuna varılmıştır. Irmak ve Erdoğan (2015)'ın da ifade ettiği üzere ergenler kendilerini zorlayan topluma ve ebeveynlerine karşı interneti ve dijital oyunları isyan aracı olarak da kullanabilmektedir. $\mathrm{Bu}$ nedenle gençlerde bilinçli ve kontrollü internet ve dijital oyun kullanma davranışlarının oluşmasında temel ilke ailede güven, demokrasi, destek, güçlü iletişim ve olumlu ebeveyn-çocuk ilişkisinin geliştirilmesidir (Irmak ve Erdoğan, 2015). Tüm bunlar kapsamında çağın vebası olan dijital oyun bağımlılığının engellenmesi için ebeveynlerin çocuklarını dijital ortamlardan uzaklaştırarak spor ve fiziksel aktiviteye yönlendirmesi önerilmektedir. Aksi halde geleceğimizin temellerini oluşturan ortaokul öğrencilerinde saldırganlık gibi istenmeyen olumsuz duygu ve davranışları taşıması kaçınılmazdır. 


\title{
EXTENDED ABSTRACT
}

\section{Digital Game Addiction and Aggression in Secondary School Students}

\author{
Burcu Güvendi - Gönül Tekkurşun Demir - Burçak Keskin \\ İstanbul University, Gazi University, İstanbul University
}

Aggression, while sometimes acts as a shield that protects the individual, sometimes it can also have negative consequences for both the individual and the other person or objects. It is observed that particularly the individuals who cannot communicate with each other, unable to understand each other get angry or resort to aggressive behavior in order to have their way or to cope with frustration (Gültekin, 2008). Middle school students experiencing their adolescent period, while counting themselves as adults and adjust their attitudes and behaviors according to the adults around them, they also live their childhood (Öztürk, 2007). Game is the most important, indispensable part of the childhood and the game preferences of children play an important role on their development. In parallel to the changing life, the game and toy types of children are also affected by this change (Toran et.al., 2016). Especially the digital world, providing a playground and a tool to play, is highly popular media for the children today (Bird and Edwards, 2015). Computer and video games under the title of digital game can be addictive for the adolescents. Once the adolescents starts playing, they continuously want to play the game and are unable to keep away even though they want to. The person, through these games, can do the things they can't do in real life and takes more pleasure as the sense of achievement is experienced. However, this pleasure and sense of achievement usually cannot be experienced in the events in real life. The ambition displayed in the games are not available in real life. This can even cause fancifulness sometimes. Some games can positively affect the mental development while addiction to computer games can distance children and adolescents from reality and real life (Pe-pe, 2011). This study was carried out at the state school, which is considered to be a risky region school with intense cultural differences, high in-family population, low 
family education level and income status, high potential of showing aggressive behavior. Researching the relation of digital game with aggressive behavior in the schools located in this region and revealing its result are considered to contribute to school administration, national education and literature. In this context, the purpose of our study is to examine by determining the digital game addiction and aggression levels of middle school students and their relationship.

The study group of the research consists of 279 middle school students, 143 female and 136 male, studying at a state school in the Esenyurt district of Istanbul province, with age average of $13.89 \pm 497$. These students are observed to spend an average of $144.40 \pm 117.27$ minutes playing digital games. Also, majority of them didn't have working mothers and usually access internet through their own or their mother's telephones In the study, aggression scale and digital game addiction in children scale were used as data collection tool.

According to the average values of the digital game addiction scale for the children in the first finding of the study, it was determined that they were in the risky group. In this context, it can be said that the participants in the risky group tend to exhibit aggressive behaviors more considering the average scores. In the other findings of the study, when the participants are examined in terms of gender, a significant difference was found in the aggression and digital game addiction total score of male students compared to female students. Accordingly, it was determined that male students had higher levels of aggression and digital game addiction than female students. In this context, it can be said that male participants are more fond of digital games than female participants, devote more time to these games, and this in turn increases the feeling of aggression by moving away from socialization and empathy. In the research, it was found that the scores of the participants on the scale of aggression and digital game addiction for children differed according to the family limiting digital game playing. Accordingly, it was found that the levels of aggression and digital game addiction of the children of the families which do not limit the digital game playing were significantly higher than those of the families which limited the duration of digital game playing. In the research, it was found that the scores of the participants on the scale of aggression and 
digital game addiction for children differed according to the family supporting participation to physical activity. Accordingly, it was found that the level of aggression and digital game addiction of the children of the families which do not support participation in physical activity is significantly higher than that of the children of the families which support the participation in physical activity. In the research, it was found that the scores of the participants on the scale of aggression and digital game addiction for children differed according to the status of digital game playing. Accordingly, aggression scores of students who play digital games for 121 minutes and more are significantly higher than the students who play between 0-60 minutes. In the final finding of the research, a significantly high level relation in the positive direction is found between the aggression total dimension and digital game addiction scale total score. Conclusion: It can be said that as the digital game addiction of middle school students increases, the levels of aggression also increases. It was concluded that the digital game addiction and aggression levels of the children of the parents which do not limit the digital game playing, children which do not participate in the physical activity, children which do not regularly play sports and have high digital game playing time are high. In this context, it is recommended that parents should distance their children away from digital environments and direct them to sports and physical activity in order to prevent digital game addiction that is the plague of the age. Otherwise, it is inevitable for the middle school students who constitute the foundations of our future to carry unwanted negative emotions and behaviors such as aggression.

\section{Kaynakça / References}

Akçay, D. ve Özcebe, H. (2012). Okul öncesi eğitim alan çocukların ve ailelerinin bilgisayar oyunu oynama alışkanlıklarının değerlendirilmesi. Çocuk Dergisi, 12(2), 66-71.

Alp, M., Eraslan, M., Atay, E. ve Özmutlu, İ. (2014). Düzenli spor yapan ve yapmayan çocukların sosyo-demografik özelliklerine göre saldırganlık düzeylerinin incelenmesi. Kafkas Üniversitesi, E-Kafkas Eğitim Araştırmaları Dergisi, 1(1), 26-30. 
Bird, J. ve Edwards, S. (2015). Children learning to use technologies through play: a digital play framework. British Journal of Educational Technology,46(6), 1149-1160.

Budak, S. (2000). Psikoloji Sözlüğ̈̈. Ankara: Bilim ve Sanat Yayınları.

Burak, Y. ve Ahmetoğlu, E. (2015). Bilgisayar oyunlarının çocukların saldırganlık düzeylerine etkisinin incelenmesi. Turkish Studies. 10(11), 363-382.

Çakır, H. (2013). Bilgisayar oyunlarına ilişkin ailelerin görüşleri ve öğrenci üzerindeki etkilerinin belirlenmesi. Mersin Üniversitesi Eğitim Fakültesi Dergisi, 9(2), 138-150.

Çebi, M., Yamak, B. ve Öztürk, M. (2016). 11-14 yaş çağındaki çocukların spor yapma alışkanlığının duygu kontrolü üzerine etkilerinin incelenmesi. Amasya Üniversitesi Eğitim Fakültesi Dergisi, 5(2), 468482.

Demir, G. T. ve Bozkurt, T. M. (2019). Dijital oyun oynama tutumu ölçeği (dootö): Geçerlik ve güvenirlik çalışması. Sportif Bakış: Spor ve Eğitim Bilimleri Dergisi, 6(1), 1-18.

Demir, G. T. ve Cicioğlu, H. İ. (2019). Fiziksel aktiviteye katilim motivasyonu ile dijital oyun oynama motivasyonu arasindaki ilişkinin incelenmesi. Spormetre, 15(4), 2479-2492.

Demir, G. T. ve Hazar, Z. (2018). Dijital oyun oynama motivasyonu ölçeği (DOOMÖ): geçerlik ve güvenirlik çalışması. Beden Egitimi ve Spor Bilimleri Dergisi, 12(2), 128-139.

Erboy, E. (2010). İlköğretim 4.ve 5. sinıf öğrencilerinin bilgisayar oyun bağımlilı̆̆ına etki eden faktörler. Yüksek Lisans Tezi, Adnan Menderes Üniversitesi, Aydın, Türkiye.

Festl, R., Scharkow, M. ve Quandt, T. (2016). Problematic computer game use among adolescents, younger and older adults. Addiction, 108(3), 592-599.

Gökçearslan, Ş. ve Durakoğlu, A. (2014). Ortaokul öğrencilerinin bilgisayar oyunu bağımlılık düzeylerinin çeşitli değişkenlere göre incelenmesi. Dicle Üniversitesi Ziya Gökalp Eğitim Fakültesi Dergisi, 23(14), 419-435.

Gökçearslan, Ş. ve Seferoğlu, S. S. (2016). Ortaokul öğrencilerinin internet kullanım biçimleri: riskli davranışlar ve fırsatlar. Kastamonu Ĕ̆itim Dergisi, 24(1), 383-404. 
Gönültaş, O. ve Atıc1, M. (2014). Ortaokul son sınıf öğrencilerinin öfke düzeyleri ve saldırganlık düzeylerinin bazı değişkenlere göre incelenmesi. Ç.Ü. Sosyal Bilimler Enstitüsü Dergisi, 23(1), 370-386.

Gültekin, F. (2008). Saldırganlık ve öfkeyi azaltma programının ilköğretim ikinci kademe öğrencilerinin saldırganlık ve öfke düzeyleri üzerindeki etkisi. Doktora Tezi. Hacettepe Üniversitesi, Ankara, Türkiye.

Hazar, Z., Demir, G. T., Namlı, S. ve Türkeli, A. (2017). Ortaokul öğrencilerinin dijital oyun bağımlılı̆̆ı ve fiziksel aktivite düzeyleri arasındaki ilişkinin incelenmesi. Niğde Üniversitesi Beden Eğitimi ve Spor Bilimleri Dergisi, 11(3), 320-332.

Hazar, Z. ve Hazar, M. (2017). Çocuklar için dijital oyun bağımlılığı ölçeği. Journal of Human Sciences, 14(1), 203-216.

Horzum, M. B. (2011). İlköğretim öğrencilerinin bilgisayar oyunu bağımlılık düzeylerinin çeşitli değişkenlere göre incelenmesi. Eğitim ve Bilim, 36(159), 57-68.

Horzum, M. B., Ayas, T. ve Balta, Ö. Ç. (2008). Çocuklar için bilgisayar oyun bağımlılı̆̆ı ölçeği. Türk Psikolojik Danışma ve Rehberlik Dergisi, 3(30), 76-88.

Irles, D. L. ve Gomis, M. L. (2015). Impulsiveness and video game addiction- impulsividad y adicción a los videojuegos. Health and Addictions. 16(1), 33-40

Irmak, Y. A. ve Erdoğan, S. (2016). Ergen ve genç erişkinlerde dijital oyunbağımlılığı: güncel bir bakış. Türk Psikiyatri Dergisi, 27(2), 128-137.

Kaplan, B. ve Aksel, E. Ş. (2013). Ergenlerde bağlanma ve saldırganlık davranışları arasındaki ilişkinin incelenmesi. Nesne Psikoloji Dergisi (NPD), 1(1,) 20-49.

Karaaslan, A. İ. (2015). Dijital oyunlar ve dijital şiddet farkındalığı: ebeveyn ve çocuklar üzerinde yapılan karşılaştırmalı bir analiz. Uluslararası Sosyal Araştırmalar Dergisi, 8(369), 806-818.

Kars, B. G. (2010). Şiddet içerikli bilgisayar oyunlarının çocuklarda saldırganlığa etkisi. Yayınlanmamış Yüksek Lisans Tezi. Ankara Üniversitesi, Ankara, Türkiye.

Kaya, A. B. (2013) Çevrimiçi oyun bağımlılı̆̆ı ölçeğinin geliştirilmesi: geçerlik ve güvenirlik çalışması. Yayınlanmamış Yüksek Lisans Tezi. Gaziosmanpaşa Üniversitesi, Tokat, Türkiye. 
Kaya, B. A. (2013). Çevrimiçi oyun bağımlılığı ölçeğinin geliştirilmesi. Yüksek Lisans Tezi, Gaziosmanpaşa Üniversitesi, Tokat, Türkiye.

Kneer, J., Rieger, D., Ivory, J. D. ve Ferguson, C. (2014). Awareness of risk factors for digital game addiction: interviewing players and counselors. Int Journal of Ment Health Addiction, 12(8), 585-599.

Koçak, H. ve Köse, Z. (2014). Ergenlerin bilgisayar oyunu oynama alışkanlıkları ve sosyalleşme süreçleri üzerine bir araştırma:Kütahya ili örneği. Dumlupınar Üniversitesi Sosyal Bilimler Dergisi, Özel Sayısı, 21-32.

Kulaksızoğlu, A. (2002). Ergenlik Psikolojisi. İstanbul: Remzi Kitapevi.

Öztürk, D. (2007). Bilgisayar oyunlarının çocukların bedensel ve duyuşsalgelişimleri üzerindeki etkisinin incelenmesi. Yayınlanmamış Yüksek Lisans Tezi, Dokuz Eylül Üniversitesi, İzmir, Türkiye.

Pepe, K. (2011). A study on playing of computer games, class success and attitudes of parents to primary school students. Educational Research And Reviews, 6(9), 657-663.

Toksöz, M. R. (1999). Yeni bir medya türü olarak etkileşimli bilgisayar oyunları. Yayımlanmamış Yüksek Lisans Tezi. Ankara Üniversitesi,Ankara, Türkiye.

Toran, M., Ulusoy, Z., Aydın, B., Deveci, T. ve Akbulut, A. (2016).Çocukların dijital oyun kullanımına ilişkin annelerin görüşlerinin değerlendirilmesi. Kastamonu Eğitim Dergisi, 24(5), 2263-2278.

Torun, F., Akçay, A. ve Çoklar, A. N. (2015). Bilgisayar oyunlarının ortaokul öğrencilerinin akademik davranış ve sosyal yaşam üzerine etkilerinin incelenmesi, Karaelmas Journal of Educational Sciences, 3, 25-35

Törüner, K. E. ve Büyükgönenç, L. (2012) Çocuk sağllğ̆ temel hemşirelik yaklaşımları. Ankara:Göktuğ Yayıncılık.

Yavuzer, Y. (2011). Okullarda saldırganlık/şiddet: Okul ve öğretmenle ilgili risk faktörleri ve önleme stratejileri. Millı̂ Ĕ̆itim, 192, 43-61.

Y1lmaz, S. (2013). Spor yapan ve yapmayan ortaöğretim öğrencilerinin empatik eğilimleri ile saldırganlık düzeyleri arasındaki ilişkinin incelenmesi. Yayınlanmamış Yüksek Lisans Tezi. Yeditepe Üniversitesi, İstanbul, Türkiye. 


\section{Kaynakça Bilgisi / Citation Information}

Güvendi, B., Tekkurşun-Demir, G. ve Keskin, B. (2019). Ortaokul öğrencilerinde dijital oyun bağımlılığı ve saldırganlık. OPUSUluslararası Toplum Araştırmaları Dergisi, 11(18), 1194-1217. DOI: 10.26466-/opus.547092 